\title{
51 COMMUNITY BASED DISASTER MANAGEMENT
}

\author{
Oleh : \\ Ridwan Herianto, Soni Akhmad Nulhaqim, \& Hadiyanto A. Rachim
}

Email:

heriantoridwan@gmail.com; soninulhakim@yahoo.com; hrachim@gmail.com

\begin{abstract}
Abstrak
Urgensi dari manajemen bencana adalah pentingnya perubahan paradigma penanggulangan bencana yang bergeser dari tanggap darurat kepada pendekatan mitigasi dan preparadness. Hal yang paling mendesak adalah menumbuhkan kesadaran dan kemampuan masyarakat untuk melindungi diri sendiri dari ancaman dan resiko bencana. Penciptaan community-based disaster dengan kata lain membangun ketahanan masyarakat dalam menghadapi bencana baik pada sebelum, saat terjadi bencana, maupun pasca bencana. Dalam praktiknya dibutuhkan peran dari pekerja sosial. Peran pekerja sosial sangat dibutuhkan dalam pemberfungsian masyarakat melalui community-based disaster. Hal tersebut dapat berupa dalam pendampingan dan perancanangan community-based disaster bersama masyarakat maupun menghubungkan masyarakat sebagai basis dengan stakeholders. Dapat melalui kegiatan formal maupun informal dalam bentuk sosialisasi maupun edukasi dan simulasi. Penerapan community-based disaster tentunya memiliki kelemahan dan kunci keberhasilan tergantung pada proses dan aktualisasinya.

Kata kunci: manajemen bencana, paradigma, community based disaster management
\end{abstract}

\section{Pendahuluan}

Negara Indonesia merupakan negara yang berpotensi untuk timbulnya bencana alam, seperti gunung meletus, banjir, tanah longsor, dan masih banyak lagi peristiwa alam lainnya. Hal ini terjadi karena Indonesia terdiri dari beberapa pulau yang tersebar mulai Sabang sampai Merauke. Dalam kaitannya dengan fenomena alam tersebut dibutuhkan upaya penanggulangan bencana dengan memperhatikan faktor penyebab terjadinya bencana tersebut.

Undang-undang No. 24 tahun 2007 menyatakan bencana adalah peristiwa atau rangkaian peristiwa yang mengancam dan mengganggu kehidupan dan penghidupan masyarakat yang disebabkan oleh faktor alam dan atau faktor non alam termasuk manusia itu sendiri (karena konflik maupun teror) yang mengakibatkan timbulnya korban jiwa manusia, kerusakan lingkungan, kerugian harta benda, dan dampak psikologis.

Perlindungan masyarakat dari ancaman bencana haruslah dilakukan oleh semua pihak, seperti pemerintah, pekerja sosial, masyarakat, maupun stakeholders lain yang dapat terkait. Hal yang paling mendesak adalah menumbuhkan kesadaran dan kemampuan masyarakat untuk melindungi diri sendiri dari ancaman dan resiko bencana.

Pekerja sosial dalam praktiknya terutama pada community based practice sangat berperan dalam intervensi pengorganisasian masyarakat menghadapi bencana. Peran tersebut adalah melalui pembentukkan Community-based disaster di masyarakat. Penciptaan community-based disaster dengan kata lain membangun ketahanan masyarakat dalam menghadapi bencana pada sebelum, saat terjadi bencana, maupun pasca bencana. 


\section{Fenomena Manajemen Bencana Di Indonesia}

Penanggulangan bencana memiliki tiga siklus: Pencegahan-Tanggap Darurat-Pemulihan. Tren yang masih terjadi di Indonesia dalam berhadapan dengan bencana adalah pada tanggap darurat. Padahal meskipun tidak ada kejadian yang memerlukan tanggap darurat, seharusnya tetap ada upayaupaya permanen untuk pencegahan. Dalam tahap pencegahan dengan adanya edukasi terhadap masyarakat agar bergerak secara mandiri dan gotong royong dalam berhadapan dengan bencana.

Meskipun kita masih belum memiliki teknologi secanggih negara lain tetapi itu bukanlah alasan bahwa kita tidak mementingkan pentingnya pencegahan bencana dalam pra darurat (pencegahan). Kita memiliki sumber daya manusia yang banyak yang berpotensi diarahkan untuk lebih "dewasa" dalam berhadapan dengan bencana.

Jika dibandingkan dengan Jepang yang merupakan negara yang sama rawannya dengan Indonesia terkait bencana, ada beberapa perbedaan signifikan antara manajemen bencana ala Jepang dengan yang ada di negeri ini. Di Jepang semakin sering bencana, semakin terlatih dan semakin baik pola penanganan bencana. Berbeda dengan di Indonesia, meski sering dilanda bencana, akan tetapi kapasitas bangsa ini dalam menanggulangi bencana nyaris belum banyak berubah. Poin penting yang dapat diambil adalah perlunya perubahan paradigma masyarakat Indonesia untuk bergerak secara mandiri dan gotong royong (mempersiapkan diri) bukan berpasrah dan hanya menunggu bantuan tanggap darurat pemerintah dalam menghadapi bencana.

Selain itu jika berbicara tentang pemerintah, maka akan terkait dengan kerawanan yang terjadi pada badan penanggulangan bencana di Indonesia(BNPB dan BPBD) yang hanya diisi dengan personel dan peralatan ala kadarnya. Mereka lebih mengandalkan pada personilyang dipinjam dari instansi lain seperti dari Kementrian PU, Kementrian Kesehatan, Kementrian Sosial, bahkan hingga BPPT atau Bakosurtanal dalam bentuk Tim Satuan Respon Cepat (SRC) atau Taruna Siaga Bencana (TAGANA). Teorinya, personil pinjaman ini sudah sepakat siap dikerahkan sewaktu-waktu ada bencana. Kenyataan di lapangan tidak semudah itu. kadang-kadang anggota SRC ataupun TAGANA sedang menghadapi tugas pokok sehari-hari di instansinya. Dan tidak selalu mudah untuk setiap saat meninggalkan tugas pokoknya tersebut dan dikerahkan ke daerah bencana.

Berdasarkan pembahasan tersebut, jika kita ambil sebuah contoh kasus bencana yang pernah terjadi dan membandingkan manajemen bencana di Indonesia dengan Jepang seperti gempa. Pada hal pra bencanalah yang begitu membedakan manajemen bencana di Indonesia dengan Jepang. Kalau di Indonesia proses pencegahan bencana hanya pada edukasi sederhana seperti tindakan apa yang dilakukan saat gempa (seperti berlindung di bawah meja) dan sasarannya kebanyakan anak sekolah. Selain itu dari sisi lain, masyarakat Indonesia cenderung larut dalam rasa kehilangan setelah bencana. Sedangkan di Jepang pada proses pencegahan sudah dibentuk komunitas yang berbasis masyarakat yang berfungsi untuk bergerak secara mandiri dan gotong royong dan terudukasi dengan baik sehingga masyarakat Jepang sudah terlatih dengan disiplin dan ketika bencana sudah terjadi, mereka tidak larut dalam kesedihan dan segera saling membahu untuk bangkit.

\section{Pembaruan Manajemen Bencana di Indonesia}

Dari pembahasan sebelumnya dapat dikatakan bahwa ada beberapa hal yang perlu dikritisi dari penanganan bencana di Indonesia:

- Pemerintah masih belum maksimal dalam penangan bencana.

- Perlunya paradigma penanggulangan bencana yang bergeser dari tanggap darurat kepada pendekatan mitigasi dan preparadness.

- Perlunya perubahan paradigma masyarakat Indonesia dalam berhadapan dengan bencana, dari yang berpasrah menjadi menyiapkan diri dalam berhadapan dengan bencana.

- Community based disaster management adalah opsi yang menawarkan solusi terhadap penanganan bencana di Indonesia yang lebih baik. 
Melihat betapa pentingnya manajemen bencana di Indonesia kita tidak dapat menyalahkan berbagai pihak, justru lebih baik merefleksi diri dan membangun karakter manusia yang mau bersama-sama melakukan perubahan pada manajemen bencana. Dengan kata lain penciptaan komunitas yang siap menghadapi bencana. Komunitas ini tentunya akan diberi edukasi dan pendampingan agar dapat mempersiapkan diri menghadapi bencana yang terkadang datang begitu saja. Juga agar memiliki paradigma yang baru dalam memandang bencana, bukan untuk berpasrah tetapi menyiapkan diri.

\section{Community Based Disaster Management (CBDM)}

Berangkat dari pemikiran bahwa ketika masyarakat dapat mengatasi masalahnya sendiri maka otomatis masyarakat tersebut sudah dapat berdaya atau dengan kata lain berfungsi secara sosial. Demikian pula dalam menghadapi bencana yang merupakan masalah sosial. Berdasarkan pemikiran tersebut, hadirlah Community Based Disaster Management (CBDM) sebagai sikap baru untuk masyarakat Indonesia dalam berhadapan dengan bencana.

Community Based Disaster Management (CBDM) adalah sebuah pendekatan yang mendorong komunitas akar rumput dalam mengelola risiko bencana lokal setempat. Upaya tersebut memerlukan serangkaian upaya dalam melakukan interpretasi sendiri atas ancaman dan risiko bencana yang dihadapinya, melakukan prioritas penanganan/pengurangan risiko bencana yang dihadapinya, mengurangi serta memantau dan mengevaluasi kinerjanya sendiri dalam upaya pengurangan bencana. Namun pokok dari keduanya adalah penyelenggaraan yang seoptimal mungkin memobilisasi sumber daya yang dimiliki dan yang dikuasainya serta merupakan bagian internal dari kehidupan keseharian komunitas (Paripurno, 2006a).

Community-based disaster membantu masyarakat mengorganisir dirinya untuk mandiri menghadapi bencana baik dari pra, saat terjadi, dan pasca bencana. Selain hal yang telah disebutkan, pentingnya perubahan paradigma penanggulangan bencana yang bergeser dari tanggap darurat kepada pendekatan mitigasi dan preparadness adalah hal utama. Community-based disaster dapat membantu meminimalisir korban bencana, kerugian yang diakibatkan bencana, maupun ketergantungan terhadap bantuan. Pentingnya penciptaan community-based disaster tentunya perlu didukung dengan penciptaan ruang yang dapat memfasilitasi pekerja social sebagai salah satu pihak yang bergerak di setting primer dan sekunder manajemen bencana yang berbasis komunitas. Hal tersebut dapat berupa dalam pendampingan dan perancanangan community-based disaster bersama masyarakat maupun menghubungkan masyarakat sebagai basis dengan stakeholders. Dapat melalui kegiatan formal maupun informal dalam bentuk sosialisasi maupun edukasi dan simulasi. Melalui berbagai kegiatan pelatihan formal/informal fasilitator masyarakat maupun relawan-relawan desa menekankan pada beberapa hal: (a) pengenalan konsep dasar pengurangan resiko bencana, (b) pengurangan risiko bencana berbasis masyarakat, (c) pelatihan pengenalan standar minimun dalam situasi darurat, (d) pelatihan pertolongan pertama gawat darurat (e) gender dan bencana (f) penyusunan rencana kontijensi kedaruratan dan standar operasional dan $(\mathrm{g})$ teknis manajemen darurat dan berbagai materi dasar yang dianggap relevan. Berikut tahapan untuk mengelola bencana dengan baik dan aman:

1. Pra Bencana

1.1 Kesiagaan

1.2 Peringatan Dini

1.3 Mitigasi

2. Saat Bencana

\subsection{Tanggap Darurat}

3. Pasca Bencana

3.1 Rehabilitasi

3.2 Rekonstruksi 


\section{Kelemahan Dalam Manajemen Bencana}

Walau bagaimanapun baiknya prosedur dan sistem yang dibangun jika tidak dilakukan dengan konsisten tentu tidak akan berhasil dengan baik. Oleh karena itu, perlu diperhatikan berbagai hal yang dapat mengganggu kelancaran dan keberhasilan manajemen bencana karena pada dasarnya sebaik apapun manajemen bencana pasti tetap saja ada celah yang dapat melemahkan.

Menurut penelitian National Safety Council (Carl Griffith, National Safety Council Utilities Division Manager) ada beberapa faktor yang menyebabkan kegagalan sistem manajemen bencana dalam suatu organisasi yaitu:

1. Kurangnya dukungan manajemen puncak

Manajemen bencana sering hanya menjadi retorika dan tidak didukung secara politis dan tekhnis. Tanpa dukungan manajemen tentu program manajemen bencana tidak akan berhasil baik.

2. Kurangnya keterlibatan dan dukungan pekerja dan masyarakat

Program manajemen bencana tidak akan berhasil jika tidak didukung oleh semua pihak, termasuk masyarakat atau anggota pekerja yang akan menjadi subyek dalam proses tanggap darurat.

3. Kurang atau tidak ada perencanaan

Manajemen bencana juga tidak dilengkapi dengan perencanaan yang baik sehingga ketika terjadi bencana semua prosedur berantakan.

4. Kurangnya pelatihan dan pendidikan

Tidak dilakukan pembinaan dan pelatihan yang diperlukan untuk masing-masing bencana baik untuk tim penanggulangan maupun untuk anggota masyarakat yang terkena bencana.

5. Tidak ada penanggung jawab yang ditunjuk khusus untuk mengkoordinir sistem tanggap darurat

6. Sistem tanggap darurat tidak dievaluasi atau disempurnakan secara berkala

Kebiasaan yang paling buruk adalah tidak pernah melakukan evaluasi, terutama jika bencana tidak pernah datang, sehingga program bencana terlupakan.

7. Sistem komunikasi dan peringatan dini tidak memadai. Sebagai akbatnya, ketika terjadi bencana semua pihak panik dan prosedur tidak berjalan sebagaimana yang diharapkan. Tidak terintegrasi dengan prosedur operasi misalnya untuk mematikan mesin atau pabrik.

8. Pekerja tidak dijelaskan mengenai tindakan atau langkah yang dilakukan jika terjadi keadaan darurat

Seluruh kelemahan di atas dapat teratasi jika seluruh elemen tanggap darurat di atas dijalankan dengan baik dan konsisten.

\section{Kunci Keberhasilan}

Pengembangan manajemen bencana memang tidak mudah dan memerlukan kerja keras dan berkesinambungan. Untuk mencapai keberhasilan dalam menerapkan dan mengembangkan manajemen bencana diperlukan hal sebagai berikut.

a. Dukungan manajemen secara penuh dan konsisten yang ditunjukan secara nyata. Manajemen bencana harus dianggap sebagai program strategis untuk memelihara dan menjaga hasil pembangunan atau proses produksi.

b. Peran serta semua pihak yang ditunjukkan dengan keterlibatan dalam proses manajemen bencana sesuai dengan porsinya masing-masing. Semakin tinggi keberhasilannya.

c. Ketersediaan sumberdaya yang memadai untuk menangani bencana sesuai dengan kondisi dan sifat masing-masing.

\section{Penutup}


Perlindungan masyarakat dari ancaman bencana haruslah dilakukan oleh semua pihak, seperti pemerintah, pekerja sosial, masyarakat, maupun stakeholders lain yang dapat terkait. Hal yang paling mendesak adalah menumbuhkan kesadaran dan kemampuan masyarakat untuk melindungi diri sendiri dari ancaman dan resiko bencana.

Pentingnya perubahan paradigma penanggulangan bencana yang bergeser dari tanggap darurat kepada pendekatan mitigasi dan preparadness. Community-based disaster dapat membantu meminimalisir korban bencana, kerugian yang diakibatkan bencana, maupun ketergantungan terhadap bantuan. Pentingnya penciptaan community-based disaster tentunya perlu didukung dengan penciptaan setting yang dapat memfasilitasi pekerja social.

\section{Referensi Buku:}

Arief Mustofa Nur. 2009. Bencana Geologi Dan Manajemen Pengelolaannya. Modul Pelatihan. Balai Informasi dan Konservasi Kebumian Karangsambung LIPI.

Ramli, Suhatman. 2010. Pedoman Praktis Manajemen Bencana (Disaster Management). Jakarta. Dian Rakyat.

UNDP. Panduan: Pengurangan Risiko Bencana Berbasis Komunitas. 2012.

Agus Rahmat, Manajemen Mitigasi Bencana.

Eko Teguh Paripurno. Modul Manajemen Bencana Seputar Beberapa Bencana di Indonesia

Referensi Lain:

http://www.kemsos.go.id/modules.php?name=News\&file=print\&sid=469, diakses pada tanggal 4 November 2014, pukul 17.18 WIB

http://www.kemsos.go.id/modules.php?name=News\&file=article\&sid=509, diakses pada tanggal 4 November 2014, pukul 17.27 WIB

http://www.academia.edu/7280326/Penanggulangan_Bencana_dan_peran_pekerja_sosial, diakses pada tanggal 4 November 2014, pukul 17.49 WIB

http://www.scribd.com/doc/50639641/Belajar-Manajemen-Bencana-Dari-Jepang\#force_seo, diakses pada tanggal 4 November 2014, pukul 19.34 WIB 